\title{
MEDICAL PRFESSIONALISM: COMPARING VIEWS OF PUBLIC AND DOCTORS
}

\author{
Uzma Bano, Anis Ahmed*, Noreen Tassadaq** \\ Foundation University Medical College Rawalpindi Pakistan, *Benazir Bhutto Hospital Rawalpindi Medical University, Rawalpindi Pakistan, **Fauji Foundation \\ Hospital, Rawalpindi, Pakistan
}

\begin{abstract}
Objective: To compare the views of public and doctors about importance of attributes of medical professionalism. Study Design: cross-sectional comparative study. Place and Duration of Study: Study was carried out at Fauji Foundation Hospital Rawalpindi from Oct 2019 to Mar 2020. Methodology: Study included 115 public participants and 115 doctors. Their perceptions about the importance of different attributes of medical professionalism were recorded on a structured questionnaire by rating on a 5-point Likert scale of importance. Independent samples t-test was used to compare the mean scores of the public group to the mean scores of the doctors for every attribute.

Results: View of public and doctors were very similar. "Honesty and integrity, sound judgment and decision making, responsible behavior, confidentiality, professional development, abiding professional rules, and being reliable" were ranked among the top ten important attributes by both groups. On the other extreme "maintaining a high standard of living" was ranked at the bottom of list by both groups. Significant differences in views of public and doctors were found regarding attributes of social justice among doctors ( 4.4 vs $4.09, p=0.012)$ and among patients (4.43 vs $4.09, p=0.05)$ and autonomy (4.42 vs $4.2 ; p=$ 0.042).

Conclusion: The opinions of public and doctors on what constitutes medical professionalism are similar with integrity and honesty being the most important attribute and to maintain a high standard of living being the least important attribute.
\end{abstract}

Keywords: Attributes, Medical professionalism, Public perceptions.

This is an Open Access article distributed under the terms of the Creative Commons Attribution License (http://creativecommons.org/licenses/by/4.0), which permits unrestricted use, distribution, and reproduction in any medium, provided the original work is properly cited.

\section{INTRODUCTION}

Medical professionalism is an obligation on the doctors to follow the ethical principles while carrying out their professional duties ${ }^{1}$. The concept of Professionalism highlights a shift of paradigm from biomedical and technical aspect to the humane aspect of medicine $^{2}$. Recent literature has emphasized on the grooming of doctors to inculcate the attributes of honesty, altruism, integrity, respect for patients and colleagues, excellence, communication skills, discipline, and abiding the rules and laws. Opinions on what actually constitutes professionalism are in fact diverse but mostly are from medical professionals while views from the public are deficient ${ }^{3,4}$.

Professionalism has an important role in the future of medicine ${ }^{5}$. The 2002 publication of "Medical Professionalism in the new millennium: a Physician Charter" highlighted the importance of medical professionalism ${ }^{6}$. Although this document gained a lot of response; however it was also widely criticized and some authors ${ }^{7}$, pointed to a lack of public input while developing the Charter. This is further supported by the

Correspondence: Dr Uzma Bano, Professor of Medicine, Foundation University Medical College, Rawalpindi Pakistan

Received: 06 Jul 2020; revised received: 12 Feb 2021; accepted: 18 Feb 2021 recent incidents of patients' complaints of disrespect, distrust and miscommunication which indicate that the patient expectations from their health care system are not being fulfilled ${ }^{8}$. Such incidents highlight the incongruence between patients' perceptions of what a medical professional should be.

This study was an attempt to explore the areas of agreement and incongruence between the public and the doctors about what constitutes professionalism. If we recognize the congruencies and incongruencies in the views of doctors and public we can shape our training programs in a way that would improve patient care and we can improve our today's doctor to come up to the public expectations.

\section{METHODODOLOGY}

It was a hospital-based cross-sectional study carried out at Fauji Foundation Hospital Rawalpindi from October 2019 to March 2020. Calculated the sample size using the open source calculator of EpiInfo version 3. We kept the confidence interval at 95\%, level of significance at $5 \%$ and power of the test at $80 \%$. In a previous study the public rated altruism at 3.673 while in another study the doctors rated altruism at 3.849. Using this data and the above parameters the minimum sample size was 112 participants in each group i.e. the public and the doctors. 
Participants were recruited through non-probability convenience sampling; 115 public and 115 doctors were included in the study. The public group included admitted patients and their attendants in various wards and the doctors included FCPS part 2 post graduate trainees of surgery, medicine, eye, ENT, obstetrics and gynecology, pediatrics, radiology and pathology. Public participants who were not able to read or comprehend the proforma or critically ill patients were excluded from the study.

The data was collected on a structured questionnaire which was developed from the professional attributes listed in an article "medical professionalism; development and validation of the Arabian LAMPS"10, and a questionnaire used in the article "cultural similarities and differences in medical professionalism; a multi-region study".

The study questionnaire was subjected to Reliability Analysis and the Cronbach's alpha coefficient was 0.934 . The questionnaire items were then subjected to Principal Component Analysis after which it was finalized with 37 items.

SPSS version 17 was used to store and analyze the dat. Each of the professional attribute was rated on a 5point Likert scale of importance by the study participants. For every attribute a mean sore was calculated for both the groups i.e. the doctors and the public. The mean scores of the two groups were compared using the independent samples t-test while considering a $p$ value of $\leq 0.05$ as statistically significant. The attributes with a mean score of $\geq 4$ were considered as essential for a doctor.

\section{RESULTS}

We included 115 resident doctors and 115 public participants. Mean age of the public group was $34.3 \pm$ 11 years and that of doctors were $29.8 \pm 4.4$ years. The study population included $122(53 \%)$ females and 108 $(47 \%)$ males.

The data showed that the perception of the two groups with regards to importance of attributes was very similar. In view of both groups the most important attribute was "Integrity and honesty". Common attributes that were ranked in the top ten by both groups (table-I) included; 1) integrity and honesty, 2) ability to make correct decisions and judgments, 3) acting in a responsible way towards the patients, 4) having a positive approach towards professional development, 5) respecting patient privacy and confi- dentiality, 6) Abiding by the professional rules and regulations, 7) Being dependable and reliable.

At the other extreme, the attributes commonly ranked in the bottom ten by both groups (table-II) were; 1) Maintaining a high standard of living, 2) Not using professional status for personal gains, 3) Being aware of needs of the patients, 4) Accepting constructive criticism, 5) Ability to train colleagues, 6) Ability to adapt to new workplace changes.

Similarly, the attribute "maintaining a high standard of living" was rated at the bottom of list by both the groups.

Table-I: Top 10 ranked attributes by both groups.

\begin{tabular}{l|c}
\hline $\begin{array}{l}\text { Professional Attributes ranked in top 10 } \\
\text { by “Doctors" }\end{array}$ & Score \\
\hline Integrity and Honesty & $4.82 \pm 0.46$ \\
\hline $\begin{array}{l}\text { Ability to make correct judgment and } \\
\text { decision }\end{array}$ & $4.61 \pm 0.55$ \\
\hline $\begin{array}{l}\text { Positive attitude for professional } \\
\text { development }\end{array}$ & $4.55 \pm 0.63$ \\
\hline Confidentiality & $4.52 \pm 0.62$ \\
\hline Reliable \& dependable & $4.52 \pm 0.58$ \\
\hline Accountable & $4.51 \pm 0.65$ \\
\hline Abiding professional rules and regulations & $4.51 \pm 0.59$ \\
\hline Works in accordance with law & $4.51 \pm 0.62$ \\
\hline Acting responsibly towards patients & $4.49 \pm 0.59$ \\
\hline Reflecting on ones action for improvement & $4.46 \pm 0.74$ \\
\hline $\begin{array}{l}\text { Professional Attributes ranked in top 10 } \\
\text { by "Public" }\end{array}$ & Score \\
\hline Integrity and honesty & $4.68 \pm 0.62$ \\
\hline Effective communication & $4.61 \pm 0.74$ \\
\hline Abiding professional rules and regulations & $4.59 \pm 0.66$ \\
\hline $\begin{array}{l}\text { Ability to make correct judgments and } \\
\text { decisions }\end{array}$ & $4.59 \pm 0.76$ \\
\hline $\begin{array}{l}\text { Positive attitude towards professional } \\
\text { development }\end{array}$ & $4.58 \pm 0.76$ \\
\hline Acting responsibly towards patients & $4.5 \pm 0.82$ \\
\hline Punctuality & $4.48 \pm 0.83$ \\
\hline Reliable \& dependable & $4.46 \pm 0.81$ \\
\hline Confidentiality & $4.44 \pm 0.95$ \\
\hline Dedication & study groups. \\
\hline Attributes in bold and italics are common in the two & \\
\hline
\end{tabular}

Statistically significant differences in rating scores were seen with regards to these three attributes (tableIII); 1) Respecting the autonomy of patients; scores by doctors $(4.4 \pm 0.77)$ was significantly higher compared to score by the patients $(4.09 \pm 1.03)$; $p=0.012,2)$ Treating patients without prejudice and with fairness; scores by patients $(4.43 \pm 0.86)$ was significantly higher compared to score by the doctors $(4.09 \pm 1.03)$; $p=0.05$, 3) Treating other health professionals without preju- 
dice and with fairness; scores by patients $(4.42 \pm 0.74)$ was significantly higher compared to score by the doctors $(4.2 \pm 0.85) ; p=0.042$.

Table-II: Bottom 10 ranked attributes by both groups.

\begin{tabular}{|c|c|}
\hline $\begin{array}{l}\text { Professional Attributes ranked in bottom } \\
10 \text { by "Doctors" }\end{array}$ & Score \\
\hline Dressing up decently & $4.18 \pm 0.93$ \\
\hline Altruism & $4.17 \pm 0.89$ \\
\hline $\begin{array}{l}\text { Not using professional status for personal } \\
\text { gains }\end{array}$ & $4.16 \pm 0.97$ \\
\hline Accepting constructive criticism & $4.13 \pm 0.93$ \\
\hline Being aware of the needs of the patients & $4.13 \pm 0.85$ \\
\hline Ability to train the colleagues & $4.13 \pm 0.88$ \\
\hline $\begin{array}{l}\text { Giving advice to patients and colleagues } \\
\text { when needed }\end{array}$ & $4.1 \pm 0.77$ \\
\hline $\begin{array}{l}\text { Working in collaboration with colleagues } \\
\text { for common goals }\end{array}$ & $4.07 \pm 0.97$ \\
\hline Ability to adapt to new workplace changes & $4 \pm 1.03$ \\
\hline Maintaining a high standard of living & $3.81 \pm 1.14$ \\
\hline $\begin{array}{l}\text { Professional Attributes ranked in bottom } \\
10 \text { by "Public" }\end{array}$ & Score \\
\hline $\begin{array}{l}\text { Being aware of ones limitations as a } \\
\text { practitioner }\end{array}$ & $4.23 \pm 0.94$ \\
\hline $\begin{array}{l}\text { Not to use ones professional status for } \\
\text { personal gains }\end{array}$ & $4.2 \pm 1.15$ \\
\hline $\begin{array}{l}\text { Acting in a responsible way towards } \\
\text { colleagues }\end{array}$ & $4.18 \pm 0.86$ \\
\hline Accepting constructive criticism & $4.18 \pm 1.04$ \\
\hline Ability to adapt to new workplace changes & $4.17 \pm 0.96$ \\
\hline Ability to train colleagues & $4.16 \pm 0.88$ \\
\hline $\begin{array}{l}\text { Being considerate of the cultural } \\
\text { background of colleagues and patiens }\end{array}$ & $4.16 \pm 1.07$ \\
\hline Being aware of the needs of the patients & $4.18 \pm 0.87$ \\
\hline Respecting autonomy of patients & $4.09 \pm 1.03$ \\
\hline Maintaining a high standard of living & $3.73 \pm 1.11$ \\
\hline
\end{tabular}

Table-III: Attributes in which the scores were significantly between the two groups.

\begin{tabular}{l|c|c|c}
\hline Professional attribute & Doctors & Public & $\begin{array}{c}p \text { - } \\
\text { value }\end{array}$ \\
\hline $\begin{array}{l}\text { Respecting the autonomy of } \\
\text { patients }\end{array}$ & $\begin{array}{c}4.40 \pm \\
0.77\end{array}$ & $\begin{array}{c}4.09 \pm \\
1.03\end{array}$ & 0.012 \\
\hline $\begin{array}{l}\text { Treating the patients without } \\
\text { prejudice and with fairness }\end{array}$ & $\begin{array}{c}4.21 \pm \\
0.80\end{array}$ & $\begin{array}{c}4.43 \pm \\
0.86\end{array}$ & 0.050 \\
\hline $\begin{array}{l}\text { Treating other health } \\
\text { professionals without } \\
\text { prejudice and with fairness }\end{array}$ & $\begin{array}{c}4.20 \pm \\
0.85\end{array}$ & $\begin{array}{c}4.42 \pm \\
0.74\end{array}$ & 0.041 \\
\hline
\end{tabular}

\section{DISCUSSION}

Opinions regarding medical professionalism diverse ${ }^{11,12}$, and mostly represent medical and academic professionals' view point ${ }^{13}$, with substantially lesser discourse from the public perspective ${ }^{14,15}$. Patient opinion and perspective was not given consideration while developing the "Physician Charter". Gilbert et al, in a study in 2007 recognized that narrative comments from the patients and public can be very helpful in the evaluation of doctors' professionalism ${ }^{16}$. A better understanding of the public expectations from doctors can be very important while formulation the Physician Charter. Current study presents a comparison of perceptions of the public and the key stakeholders of medical profession namely the public and patients, in order to elucidate the differences and commonalities in their perceptions. Our study demonstrated a large homogeneity in the opinions of doctors and public regarding the attributes of professionalism. Overall, we found homogeneity of $70 \%$ in the top ten attributes and $60 \%$ in bottom ten attributes between the two groups. Two attributes about which the rating scores significantly different between the two groups were autonomy and social justice.

The attribute of honesty and integrity was ranked at the top by both groups. This attribute is central to probity and forms a foundation for patient trust. It encompasses nearly all aspects of clinical practice for example writing $\mathrm{CVs}$, record keeping, writing histories, and doing research ${ }^{17}$.

Two attributes related to a doctor's professional competency namely "ability to make correct decisions and judgments" and "having a positive attitude towards professional development" were ranked in the top ten by both the groups. Doctors should be clinically competent and should be committed to lifelong learning and continued medical education.

Appropriate confidentiality safeguards should be applied to disclosure of patients' information. Given the widespread use of electronic information system for compiling patient data, this obligation has now become more compelling than ever before.

The attribute ranked at the bottom by groups was "to maintain a high standard of living." The appearance of the doctors including hygiene, cleanliness, neat hair and uniform or appropriate clothing is generally considered important for public perception of profession; however both the study groups ranked it at the bottom of the list of attributes.

The Dunedin public's view about what constitutes professionalism was studied ${ }^{18}$, and it was found that "wearing formal clothes" was the least important attribute while "honesty, listening carefully, and treating with respect" were ranked at the top of list of professional qualities. Boudreau et al, in 2008 noticed that the qualities of being "healer and professional" which 
are considered an integral component of conceptual armature of professionalism were in fact absent from the patients' lexicon ${ }^{19}$.

Views were different with respect to three attributes; autonomy, social justice among patients and among other health care professionals. The might be that in our setup the public relies too much on their doctors for making decisions regarding their treatment and the concept of autonomy may not be that meaningful for them. Meanwhile, the public gave more importance to social justice than did doctors. It is the prime responsibility of the doctors to eradicate discrimination in healthcare on the basis of gender, race, ethnicity, religion or status. Huddle in 2013 also showed that the doctors have not yet accepted the importance of social justice $^{20}$.

Over the past decade the major change in medical curriculum has been to inculcate the teaching of professionalism. This ne change must be responsive to the needs of the key stakeholder i.e. "the public" 21 . The importance of patient involvement was described in the international conference titled "where's patients voice in health professional education?" held at Vancouver 22. The report of this conference recommended that "curriculum development requires more sustained input from patients".

\section{CONCLUSION}

The opinions of public and doctors on what constitutes medical professionalism are similar with integrity and honesty being the most important attribute and to maintain a high standard of living being the least important attribute. Difference in opinion between the two groups was found with regards to perception of autonomy and social justice. The product of today's health education should conform to public demands and expectations.

\section{CONFLICT OF INTEREST}

The study has no conflict of interest to be declared by any author.

\section{REFERENCES}

1. DeLoughery EP. Professionalism framings across medical schools. J Gen Intern Med 2018; 33(5): 610-11.

2. Berger AS, Niedra E, Brooks SG, Ahmed WS, Ginsburg S. Teaching professionalism in postgraduate medical education: a sys- tematic review. Acad Med 2020; 95(6): 938-46.

3. Chandratilake M, McAleer M, Gibson J, Roff S. Medical professionalism: What does the public think. Clin Med (Lond) 2010: 10(4); 364-69.

4. Stubbing EA, Helmich E, Cleland J. Medical student views of and responses to expectations of professionalism. Med Educ 2019; 53(10): 1025-36.

5. Roberts LW. High Road, Low Road: Professionalism, Trust, and Medical Education. Acad Med 2020; 95(6): 817-18.

6. American Board of Internal Medicine; ACP-ASIM Foundation. American College of Physicians-American Society of Internal Medicine; European Federation of Internal Medicine. Medical professionalism in the new millennium: a physicians' charter. Ann Intern Med 2002; 136(3): 243-46.

7. Reiser SJ, Banner RS. The charter on medical professionalism and the limits of medical power. Ann Intern Med 2003; 138(10): 844-6

8. Skär L, Söderberg S. Patients' complaints regarding healthcare encounters and communication. Nurs Open 2018; 5(2): 224-32.

9. Kim YJ, Kang SJ, Kim JW, Kim YH, Sun H. Survey of attitudes on professionalism in plastic and reconstructive surgery. Arch Plast Surg 2013; 40(2): 134-40.

10. Al-Eraky M, Chandratilake M, Wajid G, Donkers J, van Merrienboer J. Medical professionalism: development and validation of the Arabian LAMPS. Med Teach 2013; 35(1): 56-62.

11. Chandratilake M, McAleer S, Gibson J. Cultural similarities and differences in medical professionalism: a multi-region study. Med Educ 2012; 46(3): 257-66.

12. Koch T. Professionalism: An archaeology. HEC Forum 2019; 31(3): 219-32.

13. Jalil A, Mahmood QK. Young medical doctors' perspectives on professionalism: a qualitative study conducted in public hospitals in Pakistan. BMC Health Serv Res 2020; 20(1): 847-50.

14. Wing M. Delivering medical professionalism: A student's perspective. Med Teach 2020; 42(10): 1196-97.

15. Ryan G, Jackson J, Cornock M. Exploring public perspectives of e-professionalism in nursing. Nurs Manag (Harrow) 2019; 26(6): 29-35.

16. Liu GC, Harris MA, Keyton SA, Frankel RM. Use of unstructured parent narratives to evaluate medical student competencies in communication and professionalism. Ambul Pediatr 2007; 7(3): 207-13.

17. Bäckryd E. Nurturing the Virtues: Upholding professionalism in the midst of busy medical practice. J Contin Educ Health Prof 2019; 39(1): 69-72.

18. Hutchinson M, Reid J. In the eyes of the Dunedin public, what constitutes professionalism in medicine. J Prim Health Care 2011; 3(1): 10-15.

19. Boudreau JD, Jagosh J, Slee R, Macdonald ME, Steinert Y. Patients' perspectives on physicians' roles: implications for curricular reform. Acad Med 2008; 83(8): 744-53.

20. Huddle TS. The limits of social justice as an aspect of medical professionalism. J Med Philos 2013; 38(4): 369-87.

21. Martin LD. Professionalism: in the eye of the beholder. Paediatr Anaesth 2017; 27(3): 226-27.

22. Towle A. Where's the patients' voice in health professional education. Nurse Educ Pract 2006; 6(5): 300-02. 